\title{
Current Assets Management, Remuneration, and Operating Cash Flow of UAE Construction Companies
}

\author{
Haitham Nobanee ${ }^{1}$, Mohammed Haitham A. Salman ${ }^{1} \&$ Jaya Anitha Abraham ${ }^{1}$ \\ ${ }^{1}$ College of Business, Abu Dhabi University, Abu Dhabi, United Arab Emirates \\ Correspondence: Haitham Nobanee, College of Business, Abu Dhabi University, P.O. Box 59911, Abu Dhabi, United \\ Arab Emirates. E-mail: nobanee@gmail.com
}

Received: July 26, 2020

Accepted: November 3, 2020

Online Published: January 20, 2021

doi:10.5430/ijfr.v12n3p142

URL: https://doi.org/10.5430/ijfr.v12n3p142

\begin{abstract}
This paper examines the effect of current assets management and remuneration on operating cash flow of construction firms listed in the United Arab Emirates stock market before and after the financial crises of 2008. The results present a negative and significant relationship between cash conversion cycle and operating cash flow for the full sample. The results also show a negative and significant relationship between the cash conversion cycle and operating cash flow of the firms during the crisis period. This indicated that the UAE construction companies were more efficient in managing their current assets during the crisis period.
\end{abstract}

Keywords: current assets management, remuneration, cash conversion cycle, operating cash flow, small firms, financial crisis

JEL Classification: G30, G32, L25, O25

\section{Introduction}

The economy of the United Arab Emirates (UAE) is the second largest in the GCC (Gulf Cooperation Council) region, with Saudi Arabia being the largest. Though known as an economy dependent on oil for several decades since the 1970s, the UAE has been diversifying its economic activities to non-oil sectors. The real estate boom in the UAE that picked up momentum since the Eighties catering mainly to the needs of the growing tourism sector and related activities. The UAE government has channelized its oil revenues for building the infrastructure for long term economic gains. The government created a favorable business climate, a flexible legal environment that allows a hundred percent foreign ownership in Free Trade Areas, pegging of its currency to the US dollar, creating cultural diversity and potential for a high standard of living contributed to the economic growth of UAE. It reached a peak when the contribution of construction and real estate activities to the real GDP increased from 8.2 percent in the year 2012 to 10.3 percent in 2016. However, after 2016, the expansion in real GDP has been less than 3\%, Though, the international financial reports abounded with worries about the next recession, by 2017, 11,755 active projects were going on in the UAE worth more than $\$ 818.2$ billion accounting for 33\% of the total value and more than $52 \%$ of all construction activity of the GCC region(Ministry of Economy, 2019). The construction market of the UAE can be segmented into commercial, residential, industrial, infrastructure (transportation, etc.), and energy and utility. By 2018 , the total value of contracts awarded amounted to $\$ 31.5$ billion while it was $\$ 28.6$ billion in 2017(Mordor Intelligence, 2020).

Before the Great Recession of 2008, the construction sector of the UAE has been thriving and consistently contributed double-digit growth to the economy. The infrastructure and real estate sector of GCC was worth $\$ 1$ trillion and more than one-third of it was contributed by the UAE. However, the descent of the construction sector started with the financial crisis in 2008 caused by the housing bubble in the US. An estimate in a 2011 report on the GCC real estate reported that the total value of construction projects put on hold in the UAE in 2008 was worth $\$ 360$ billion. The housing sector was the epicenter of the financial crisis and real estate prices dropped 20 to 50 percent from their peaks forcing the retreat of some major foreign investors. Many projects experienced severe cash flow constraints by the year 2010. In Dubai alone, more than half of the construction projects were on hold (Domeyer, 2017). The major factors that stalled the recovery of the sector were a decline of the number of immigrants due to loss of employment, lack of confidence among foreign investors leading to reluctance in new investments, funding problems due to strict liquidity issues, and the imbalance between demand and supply (Al-Malkawi and Pillai, 2013). 
In fact in the UAE, the bankers tightened the credit policy fearing debt default by the construction companies aggravated the issues faced by the sector until 2011. Firm-specific factors such as size influenced the way firms responded to such financial issues and limited the profitability of firms. Thus, during times of economic crisis, the effective management of working capital becomes very important. An in-depth analysis of their working capital management and its effect on profitability would add value to the knowledge related to the profitability of firms. Further, working capital management in the construction sector is affected by many external macro-economic factors such as legal and tax environment, supply chain and logistic factors, the phases of projects, credit policy of the lenders, relationship with the creditors and debtors and other stakeholders (Geetam and Samanta,2017).

Remuneration as stated in the UAE Labor Law: is whatever is given to the employee in consideration of his services under the employment contract, whether in cash or in-kind, payable annually, monthly, weekly, daily, hourly, or by piece-meal or pro-rata to the production or as a commission.

The remuneration includes the high cost of living allowance, and any benefit is given to the employee in reward for his honesty or efficiency, provided always that these amounts are prescribed in the Company bylaws or the employment contract, or normally practiced or granted to the employees until they have been regarded by these as an integral part of the remuneration rather than a donation (Salman and Nobanee, 2019). The studies mentioned above outline that macro-economic scenarios coupled with financial factors such as management factors such as working capital management have a deep impact on the survival and profitability of construction companies in the region. Thus, the study of working capital management among UAE construction companies assume paramount importance. In the next section, previous literature relevant to the present context will be reviewed.

\section{Review of Literature}

The working capital strategy of a firm may get influenced by many firm-related factors such as the stage of inception, the vision, and mission of the company, and the risk-taking attitude of the management other than the external financial environment. An aggressive working capital management strategy enhances a firm's performance in the short run and has a favorable influence on profitability. A conservative strategy of working capital management is more focused on the long term goals of the company. It helps the firm gain sales growth, expand market share, and improve profitability in the long run. The stage of the business is a very important factor that influences the type of strategy required to sustain the firm's performance. At the stage of introduction, growth, and decline phase most firms face a crunch for money and hence follow aggressive working capital management. The mature firms may have accumulated funds in the form of retained profits and thus they may remain immune to the effect of high investment in working capital (Wang, et. al,2020). Therefore, working capital management has more importance in the initial three stages of the growth of a business.

Studying the working capital management of Russian automotive companies, Pirtilla et. al(2020) stressed the influence of working capital management on profitability. The study commented that the Russian automotive industry is more efficient in working capital management than their American counterparts and they work with their suppliers mostly based on trust. Further, the authors added that in a challenging economic environment such as that of Russia, the automotive industry has working capital tied up for an average of 45 days, The trend in their CCC is prolongation over the years. The Cash Conversion Cycle (CCC) measures the ability of a company to convert the existing cash into inventory or supply that can be resold to converted back to cash. It measures the number of days that the company's funds remain tied up in the form of working capital (Richard and Lauglin, 1980).

In a longitudinal study of a sample of S\&P listed firms across different sectors from 1990-2017, Boisjoly et.al (2020) demonstrated that continuous improvement programs such as Six Sigma, Total Quality Management (TQM) and lean management initiatives increase the speed and accuracy of business processes and improve cash and credit sales productivity. Similarly, the authors suggested that aggressive working capital management practices on accounts receivable turnover, inventory turnover, days payables outstanding, and cash conversion cycle boosted profitability across sectors and size. This confirmed the theory advanced by Jensen and Meckling (1976) which argued that the components of working capital namely, cash, accounts receivables, inventory, and accounts payables are important in maximizing shareholders' value of the firm. In 2020 another study analyzing the financial statements of 80 companies listed in the Tehran stock exchange, from 2002-2013 confirmed that among the components of CCC namely days account receivable, days inventory, and days account payable, only days accounts receivable has a negative and significant relationship with firm's profitability. Further, this study also showed that the different phases of the business cycle do not affect the relationship between working capital management and the firm's profitability (Pakdel and Ashrafi,2019). Liu et.al (2020) studied a sample of Chinese manufacturing firms for the period 2010-2017 and confirmed that the negative relationship between the CCC and the firm's profitability exists and is 
significant for non-state-owned enterprises than the state-owned enterprises. The moderating effect of the characteristics of the factor markets and the legal systems also significantly influence the non-state-owned enterprises than the state-owned enterprises. Seth et.al (2020) explored the relationship between working capital management and exogenous factors influencing the subsectors of 563 Indian manufacturing companies for a period of ten years from 2008 to 2018. This period reflected the economic impact of several major changes in economic policy such as the demonetization of the Indian currency and the Great recession. They found that leverage(Total debts/total assets), net fixed assets ratio(Net fixed assets/total assets), profitability (Profit after taxes/net sales), assets turnover ratio (Total income/total assets), and total assets growth rate( current year's total assets-past year's total assets/past year's total assets) influenced working capital management and firm's value significantly.

A study conducted by Kasirana et al. (2016) examined the efficiency of current assets management of small and medium organizations in Malaysia itself, showed that the small firms were less efficient in managing their working capital. Pais and Gama (2015) studied 6063 firms in Portugal covering the period from 2002 to 2009. The results indicated that decreasing inventories held and the number of days taken to settle liabilities is associated with higher corporate profitability. Similarly, Nobanee and Abraham (2015) studied the relationship between the firm's net trade cycle as a measure of the efficiency of current assets management and the liquidity of US small firms. The study employed Generalized Method of Moment Dynamic Panel-Data System Estimation with Robust Standard Errors for a sample of 5,802 US non-financial firms listed on the major US stock exchanges including the New York Stock Exchange, American Stock Exchange, NASDAQ Stock Market, and Over the Counter Market for the period 1990-2004. The findings of the study showed a negative and significant relationship between the net trade cycle and liquidity for small US firms. Madhou et.al (2015) applied a similar methodology to the data from Australian firms and focused more on the interactions of the working capital, firm characteristics, economic conditions, and the profitability of the firms. Their findings identified that profit-making firms and loss-making firms are affected by different determinants.

Zainudeen (2006) examined the efficiency of working capital management of Malaysian SMEs by investigating the relationship between the current ratio and working capital to assets ratio. However, later many researchers shifted their focus to the relationship between the cash conversion cycle and its components to evaluate the efficiency of working capital management (Rahima, 2015). Vahid et al. (2012) analyzed the effect of the different components of working capital management including the receivable collection period, inventory conversion period, payable deferral period, cash conversion cycle, and net trade cycle, on the profitability of Iranian firms. The results showed that profitability is negatively associated with various measures of working capital management.

Kayani et al. (2019) investigate the relationship between working capital management and corporate governance on firm performance for U.S. listed firms. The results show efficient working capital management and good corporate governance practices significantly affect firms' performance. Nobanee (2018) studied the relationship between working capital management and the net trade cycle for small and large construction firms listed in the UAE. This study concluded that larger firms had a negative and significant relationship that existed between the net trade cycle and profitability irrespective of size. During the economic crisis, it was found that smaller firms fared better.

Kim and Kim (2011) examined the causal relationship between the current account and the capital account for Korean companies. The results show the existence of bidirectional causality between the current account and the capital account. Jay and Johnson (2011) examined the impact of cash conversion cycle and liquidity, invested capital, and profitability of U.S. manufacturing firms, the findings of the study indicate that cash conversion cycle is significantly related to all three of these aspects.

Working capital management influenced the financial performance of smaller firms more than that of larger firms. In 2020, a study analyzing the financial statements of 30 SMEs for the period from 2014-2018, using panel regression, it was concluded that the estimated average CCC of 18 days is too high for the sample SMEs and hampered their profitability(Oladimeji and Aladejebi, 2020). Similarly, Sadiq (2017) studied 28 firms in Nigeria from 2010 to 2014 using panel regression and found that size, growth of sales, and earnings influence the profitability of SMEs. Afeef(2011) examined 40 firms listed in Karachi Stock Exchange, Pakistan, for the period 2003-2008 and concluded that short-term debts, the dominant component in the current assets of small firms affect their profitability more than any other components. Nguyen et. al(2020) in a study of 226 firms listed on the Vietnamese stock market including Ha Noi Stock Exchange and Ho Chi Minh Stock Exchange for 9 years from 2010 to 2018, showed a negative impact of CCC on working capital management by applying Ordinary Least Squares(OLS) and Fixed Effects Model (FEM). It implied that the optimization of working capital management can be achieved by shortening the time to collect payables, accelerating the flow of inventory, and giving shorter credit periods. It also demonstrated that the 
profitability of firms gets influenced by the sales growth rate, size of the firm leverage, and age. The smaller firms have relatively limited access to external sources of finance. Thus they rely mainly on internal financial resources, trade credits, and short-term loans to support account receivables and inventories.

A study by Chisti (2012) on the Indian firms showed that a negative and significant relationship between the length of the inventory conversion period, receivable collection period, and cash conversion cycle, however, the payables deferral period showed a positive relationship. Nobanee and Ellili (2015a) observed a strongly negative and significant relationship between the net trade cycle and performance for large construction firms in Kuwait. In a comprehensive study, Shin and Soenen (1998) reported a negative and significant relationship between the net trade cycle and the firm's profitability of U.S. listed companies. Several similar studies were across the globe confirmed similar results.

Most of the scientific inquiry on the connection between working capital management and the firm's profitability centered around the application of quantitative techniques. Several studies that focus on qualitative techniques also exist (Chand and Seth, 2020). They stress the need for effective employee empowerment, recognition of productive work, performance-based incentives, positive work culture, and informal interaction for improving productivity in general.

Nobanee and Ellili, (2015b) examined the relationship between the receivable conversion period as a measure of credit policy and profitability of construction firms listed in Saudi Arabia. The findings showed a negative and significant effect of the receivable conversion period on the profitability. A similar study conducted by Jayarathne (2014) on the efficiency of working capital management and profitability of companies listed on the Sri Lankan stock market showed that a liberal credit policy would increase the firm's profitability. Nobanee and Alhajjar (2014) suggested an optimal operating cycle, cash conversion cycle, and net trade cycle accurately measure working capital management efficiency. If the current assets' levels are optimal, total holding and opportunity costs are minimized. The present study attempts to expand the research in this area to the UAE construction companies during the 2008 crisis and post-crisis periods.

\section{Data and Methods}

The dataset included 122 year-firm observations of all construction companies listed on the Abu Dhabi Stock Exchange and Dubai Financial Market during the period 2003-2013. We hypothesized a negative and significant relationship between the efficiency of the current assets management measured by the cash conversion cycle and firms' operating cash flows to sales for the small and large construction firms listed on the UAE markets before and after the 2008 financial crisis. The cash conversion cycle is equal to the receivable conversion period plus the inventory conversion cycle minus the payables deferral period (Richards and Laughlin., 1980; Nobanee and Abraham, 2014). The study used a GMM Dynamic Panel-Data with Robust estimation. This method was preferred to avoid joint correlation between independent variables and the dependent variable, to avoid unobserved province-specific effects correlated with our independent variables, and to control for any unobserved province(locality) specific effects (Nobanee et al., 2011, Nobanee and Ellili, 2015a). The robust estimation does not require any quality measures.

This estimation leads to the following equation:

$$
c f s_{i t}=\alpha+\beta_{1} c f s_{i t_{-1}}+\beta_{2} c c c_{i t}+\varepsilon_{i t}
$$

Where $\left(c f s_{i t}\right)$ is the first difference of operating cash flow to sales. $\left(c f s_{t-1}\right)$ is the differenced lagged dependent variable

of operating cash flow to sales, $\left(c c c_{i t}\right)$ is the first difference of net cash conversion cycle (Shin and Soenen, 1998,

Nobanee and Ellili, 2015b). This estimation method was used for all the construction companies, irrespective of size, and both crisis and non-crisis periods.

\section{Results and Discussion}

The results presented in Table 1 below, indicated that the coefficients of the relationship between the cash conversion cycle and operating cash flows for all construction firms were significant and negative. Thus, the shorter the cash conversion cycle, the higher the operating cash flow. This meant that construction firms used their current assets efficiently increasing their operating cash flow. The results also showed that the coefficient for the crisis period is 
significant and negative. Thus, the UAE-listed construction firms managed their current assets efficiently during the crisis period.

Table 1. Results of dynamic panel data two-steps robust system estimation

\begin{tabular}{llcccc}
\hline Sample/Variables & All & Small & Large & Crisis & Non-Crisis \\
\hline CCC & $-0.0001532 * *$ & -0.0000611 & -0.0003384 & $-0.0002267 * *$ & -0.0506368 \\
Lag-CFS & -.008710000 & 0.0052660 & 0.1920195 & -0.0025887 & 0.0000822 \\
\hline
\end{tabular}

Table 1 reports the results of the dynamic panel-data two- steps robust system estimation for the relationship between the cash conversion cycle and the firm's operating cash flow to sales for UAE listed construction firms. (CFS) is the operating cash flow to sales, (CCC) is the cash conversion cycle, (Lag-CFS) is the lagged dependent variable. This robust estimation does not require any quality measures.

$* *$ significant at $99 \%$ confidence level.

\section{Conclusion}

The main aim of this paper was to examine the effect of liquidity management on the operating cash flow of construction firms listed on the United Arab Emirates stock markets before and after the Great Recession. Dynamic panel data two- steps robust system estimation was used in this study for the data from 2003 to 2013. The analysis was applied at the levels of the full sample and divisions of the sample by the crisis and post-crisis periods, and by size. The results showed a negative and significant relationship between the cash conversion cycle as a comprehensive measure of the efficiency in current assets management and operating cash flow for the full sample. The results also showed a negative and significant relationship between the cash conversion cycle and operating cash flow of UAE construction firms during crisis periods. This indicated that the UAE construction companies are more efficient in managing their current assets during crisis periods.

The major limitation of the study was the timely availability of data for the relevant period. Also, the GCC in general, and the UAE, in particular, have scant literature available on the financial performance of the construction companies. It is within these limitations that this study was completed. This study adds value to the literature in the construction sector in the current context of the worldwide impact of COVID-19 wherein all companies irrespective of size, are affected by the liquidity crunch. Thus the findings will help the firms survive the adverse impact in the pandemic affected scenario.

\section{References}

Afeef, M. (2011). Analyzing the impact of working capital management on the profitability of SME's in Pakistan. International Journal of Business and Social Science, 2(22), 173-183. Retrieved from www.ijbssnet.com

Al-malkawi, H. N., \& Pillai, R. (2013). The Impact of Financial Crisis on UAE Real Estate and Construction Sector: Analysis and Implication. Humanomics, 29(2), 115-135. Retrieved from https://www.emeraldinsight.com/doi/pdfplus/10.1108/08288661311319184

Boisjoly, R. P, Conine, T. E. Jr., \& McDonald, IV. M. B. (2020). Working Capital Management: Financial and Valuation Implications. Journal of Business Research, 108 (1-8). https://doi.org/10.1016/j.jbusres.2019.09.025

Chadha, S., \& Seth, H. (2020). Ownership structure and capital structure: a panel data study. International Journal of Business Innovation and Research. https://doi.org/10.1504/IJBIR.2020.10024975

Chisti, K. (2012). The Relationship between Working Capital Efficiency snd Profitability. The Journal of Accounting and Management, 2(3), 21-45.

Enqvista, J., Grahamb, M., \& Nikkinenc, J. (2014). The Impact of Working Capital Management on Firm Profitability in Different Business Cycles: Evidence from Finland. Research in International Business and Finance, 32, 36-49.

Geetam, S., \& Samanta, P. K. (2017). Working capital management and profitability: An empirical analysis of infrastructure companies. ASBM Journal of Management, 10(1), 29-39. Retrieved from http://adu-lib-database.idm.oclc.org/login?url=https://search-proquest-com.adu-lib-database.idm.oclc.org/docvie w/1862660385? accountid=26149 
Jay, J., \& Johnson, C. (2011). Cash Conversion Cycle Management in Small Firms: Relationships with Liquidity, Invested Capital, and Firm Performance. Journal of Small Business \& Entrepreneurship, 24(3), 381-396.

Jayarathne, T. (2014). Impact of Working Capital Management on Profitability: Evidence from Listed Companies in Sri Lanka. Proceedings of the 3rd International Conference on Management and Economics, pp. 26-27.

Jensen, M. C., \& Meckling, W. H. (1976). The Theory of the Firm: Managerial Behavior,Agency Costs and Ownership Structure. Journal of Financial Economics, 3(4), 305-360.

Kasirana, F., Mohamad, N., \& Chinc, O. (2016). Working Capital Management Efficiency: A Study on the Small Medium Enterprise in Malaysia. Procedia Economics and Finance, 35, 297-303.

Kayani, W., De Silva, T., \& Gan, C. (2019). Working Capital Management and Corporate Governance: A New Pathway for Assessing Firm Performance. Applied Economics Letters, 26(11), 938-942.

Kim, C., \& Kim, D. (2011). Do Capital Inflows Cause Current Account Deficits?. Applied Economics Letters, 18(5), 497-500.

Liu, T. R. N., Yang, H., Xiao, Y., \& Hu. (2019). Working Capital Management and Firm's Performance in China. Asian Review of Accounting, 27(4), 546-562. https://doi.org/10.1108/ARA-04-2018-0099

Madhou, A., Moosa, I., \& Ramiah, V. (2015). Working Capital as a Determinant of Corporate Profitability. Review of Pacific Basin Financial Markets and Policies, 18(4). https://doi.org/10.1142/S0219091515500241

Mordor Intelligence. (2020). UAE Construction Market: Growth, Trends and Forcast (2020-2015). Retrieved from https://www.mordorintelligence.com/industry-reports/uae-construction-market

Nguyen, A. H., Phamthang, H. T., \& Nguyen, T. (2020). Impact of Working Capital Management on Firm's Profitability: Empirical Evidence from Vietnam. Journal of Asian Finance, Economics and Business, 7(3), 115-125. https://doi.org/10.13106/jafeb.2020.vol7.no3.115

Nobanee, H. (2018). Effiecient of Working capital management and Profitability of UAE construction companies: Size and Crisis Effect. Polish Journal of Management Studies, 18(2), 209-215. https://doi.org/10.17512/pjms.2018.18.2.17

Nobanee, H., \& Abraham, J. (2015). Current Assets Management of Small Enterprises. Journal of Economic Studies, 42(4), 549-560.

Nobanee, H., \& AlHajjar, M. (2014, March). An Optimal Cash Conversion Cycle. International Research Journal of Finance and Economics, (120), 13-22.

Nobanee, H., \& Ellili, N. (2015a). Working Capital Management and Performance of Kuwait Construction Companies. Corporate Ownership \& Control, 12(2), winter, 349-355.

Nobanee, H., \& Ellili, N. (2015b). Does Credit Policy Affect Performance of Saudi Construction Companies. Actual Problems of Economics, 171, 226-234.

Nobanee, H., Abdullatif, M., \& AlHajjar, M. (2011). Cash Conversion Cycle and Firm's Performance of Japanese Firms. Asian Review of Accounting, 19(2), 147-156.

Oladijebi, J. A., \& Aladejebi. (2020). The Impact of Working Capital Management on Profitability: Evidence from Selected Small Businesses in Nigeria. Journal of Small Business and Entrepreneurship Development, 8(1), 27-40. https://doi.org/10.15640/jsbed.v8n1a3

Pais, M. A., \& Gama, P. M. (2015). Working Capital Management and SME Profitability: Portuguese Evidence. International Journal of Managerial Finance, 11(3), 341-358.

Pakdel, M., \& Ashrafi, M. (2019). Relationship between Working Capital Management and the Performance of Firm in Different Business Cycles. Dutch Journal of Finance and Management, 3(1), em0057. https://doi.org/10.29333/djfm/5874

Pirtilla, M., Virolainen, V. M., Lind, L., \& Karri, T. (2020). Working Capital Management in the Russian Automotive Chain. International Journal of Production Economics, 221. https://doi.org/10.1016/j.ijpe.2019.08.009

Rahima, A. A. (2015). The effects of working capital management on SMEs profitability in Malaysia. Masters Thesis.

Richards, V. D., \& Laughlin, E. J. (1980). A Cash Conversion Cycle Appproach to Liquidity Analysis. Financial Management, 9, 32-38. 
Sadiq, R. (2017). Impact of working capital management on small and medium enterprises' performance in Nigeria. Arabian Journal of Business and Management Review, 7, 2-5. https://doi.org/10.4172/2223-5833.1000285

Salman, H., \& Nobanee, H. (2019). Recent Developments in Corporate Governance Codes in the GCC Region. Research in World Economy, 10(3), 108-126.

Seth, H., Chadha, S., Ruparel, N., Arora, P. K., \& Sharma, S. K. (2020). Assessing working capital management efficiency of Indian manufacturing exporters. Managerial Finance. https://doi.org/10.1108/MF-02-2019-0076

Shin, H., \& Soenen, L. (1998). Efficiency of Working Capital and Corporate Profitability. Journal Financial Practice and Education, 8, 37-45.

UAE Ministry of Economy. (2017). Annual Economic Report (25th ed.). Retrieved from https://www.economy.gov.ae/EconomicalReportsEn/MOE\%20Annual\%20Report\%202017_English.pdf

Vahid, T., Elham, G., Mohsen, K., \& Mohammadreza, E. (2012). Working Capital Management and Corporate Performance: Evidence from Iranian Companies. Procedia - Social and Behavioral Sciences, 62, 1313-1318.

Wang, Z., Akbar, M., \& Akbar, A. (2020). The Interplay between Working Capital Management and a Firm's Financial Performance across theCorporate Life Cycle. Sustainability, 2020(12), 1-16, 1661. https://doi.org/10.3390/su12041661

Zainudin, N. (2006). Liquidity-profitability trade-off: Is it evident among Malaysian SMEs?. International Journal of Management Studies, 13(2), 107-118.

\section{Copyrights}

Copyright for this article is retained by the author(s), with first publication rights granted to the journal.

This is an open-access article distributed under the terms and conditions of the Creative Commons Attribution license (http://creativecommons.org/licenses/by/4.0/). 